\title{
肉用牛生産における技術革新と経営変革
}

宮崎昭

\section{1. 技術革新の重要性}

技術革新が経営に大きな変革をあたらした例とし て，とくに影著に想起できるととが大正から昭和にか けての養鷄においてみられた. 昭和のはじめまでのわ が国の養鷄は，専業的なものが少なく，一般的には副 業的に一戸当たり $5 \sim 10$ 羽というきわめて小規模な飼 育で行われていた．飼育の主な目的は採卵と採肥であ った. しかし，乙のような養鵎経営から出荷される鵎 卵は数量が少なく, また, 生産費が高くなりがちであ った. そのため, 大正時代の初め頃から鷄卵が庶民的 な食材の一つになるにつれて, 需要に応じた供給が円 滑にできなくなった．その不足分が中国からの大量輸 入で補われることになった。

輸入鷄卵に対する輸入関税は明治 35 年以来かけられ ていたが，大正 8 年にはそれが免除され，中国からの 輸入量はさらに増加した. その結果, 大正後期にはわ が国の鷄畉消費量の 3 分の 1 が輸入卵となっていた. それに対して，わが国であ舀卵の国内生産を振興する 気運が高まり, 多産鷄の飼育への関心が一段之強くな った. 東京・名古屋・大阪などの大都市の周囲では専 業的な採卵経営が生まれた. しかしその一方で, 第一 次世界大戦後, 食生活の洋風化が進み鷄卵需要は著し く伸びたので, 中国からの鷄卵の輸入量がさらに増大 した. 大正13年には鵴卵に対する輸入税が復活された が，もはや鶏卵輸入の抑制は困難とみられた¹).

そういう状況の中で, 大正14年の日本畜産学会大会 で,世界に先がけて当時, 画期的ともいえた初生雊雌 雄鑑別法が発表された．乙の知見をむとにして直ちに 専門的な鑑別師の養成が行われ彼らがコンクールで技 を競った結果, まむなく雌雄鑑別が実用的に完全に行 えることになった. その結果. 従来と全く異って採卵養 䳕経営においては将来, 産卵のできる初生雌雛だけを 選んで購入することが可能となった. すなわち雌雄鑑 別の実用化とその普及によって, 従来避けることの不 可能であった購入した雛の半数が産卵には役立たない という，かつての生産性の低さを克服できるととにな
った. とくにその当時は, 現在と違って鷄肉の大部分 が廃鵴からえられ，したがって雄雊は食肉生産用にあ まり有利に取引きされなかった時代であった，そのた め, 初生敬の段階で将来不必要な雄を除外して, 必要 な雌だけを導入できることは経営に益するとてろきわ めて大きいものがあった2).

鷄の栄養に関する分野であ画期的な研究が行われ た. 鷄は総排泄腔から糞尿を一緒に排泄するので, 飼 料の消化率の測定が困難である．そこで人工肛門を設 着した鷄を用いて消化試験を行うが，以前はての手術 が難しく、また手術後の舀の管理は容易でなかった. そういうとき，鵴による飼料の消化率を人工肛門を設 着するととなく，排泄物中の全窒素と尿酸態窒素量よ り，係数を用いて粪中の成分量を算出して，消化率を 求める方法が大正 7 年にわが国で発表された. それが きっかけとなってわが国において舀の栄養に関する研 究が進み，ビタミン類，無機物などを補給すると，必 ずしあ鷄に緑慨を与えなくてもよいとと，また当時， 主として肥料として用いられ飼料とは考えられなかっ た大豆粕を主要な飼料たん白質源として用いるととが できるととが明らかにされた．当時, 養鵎用飼料の成 分としては, 緑䬲と魚粉が不可欠のあの之考えられて いたが，乙れらの研究によって従来の考え方が打破さ れだ〉.

昭和 3 年には，生産目的にあわせて過不足なく栄養 素をバランスよく含む配合飼料が開発され，販売され ることになっだ)．それを利用すれば，鶏の栄養状態 は大きく改善され生産能力は著しく高まった，それば かりか, 飼養管理の体系は, 緑飭が不要になることに より単純化され, 養鷄経営における多頭羽飼育も可能 となった．しかむこの経営における初生雔の導入は， すでに雌だけを選んで行えるととになっていたのであ る. このようにして養鵴経営における生産性は著しく 高くなった．その結果，まむなく中国からの輸入卵は 駆遂されはじめ, 昭和 6 年になると鷄卵は完全に自給 できるようになり，さらには逆に重要輸出品に指定さ れるに到った．畜産における技術革新は，経営変革に 
とって重要なきっかけとなりうるあのである1".

\section{2. 肉用牛生産技術の改善}

肉用牛における技術革新が経営変革をあたらした积 度は，羙舀におけるほど著しくはない，Neumann に よる之，アメリカにおいて1950年以降の 25 年間に，肉 用牛の 1 日当たりの增体量は約 $25 \%$ 增加した。 その結 果，肥育期間は50〜 75日間短縮され，飼料効率は約 20 \%改善された，一方，他の章産物の生産性は1960年か ら1980年までの 20 年間に，乳牛 1 頭当たりの産乳量は $30 \%$ ，産卵舀 1 羽当たりの産卵数は $54 \%$ ，また肉豚で は1 日当たり增体量が $33 \%$ ，飼料効率は $32 \%$ 向.上した と報告されている。乙れを経済的観点から評価した Zmolck らは，アメリカ人 1 人当たり 1 時間の労働に よって購入できる牛肉量が，1960年から1982年の間に 1.25倍になったと試算した。 しかし同じ時期に鶏畉は 2. 44倍，牛乳は1.67倍になったというから，牛肉関 する生産性の向上は必ずし屯十分大きかったとはいえ ない。

肉用牛生産の技術に関して，乙の間，広簌な研究が 行なわれ品種改良はもとより，雑種強勢などによる繁 殖性之増体性の向上，飼料用豰物の大量生产之それら の合理的な緰与法が飼盖標準の設定などとともに可能 となったてと,さらには動物薬の開発之普及によって, 大規模飼育が容易になるなど著しい発展がみられたに あかかわらず， 1 時間の労衝によって購入できる离産 物の量を尺度として比殡したとき，肉用牛の生産性の 向上がいかに困難なととであったかが理解できる，換 言すれば，画期的な技術革新と考えられてもそれが肉 用牛経営にとり入れられ，普遍的な技術として定着し た結果生じる経営変化は革命的なものではなくて，む しろ漸進的な改善にとどまっていたようである゙ ${ }^{5}$.

とくにわが国のように，比較的零細な肉用牛飼育が 行われている経営において，それが言えそうである. 実験的には革命的な新しい技術であっても，零細な農 業経営の現場にそのままそっくり導入されると，かえ って犠性か強いられるととさえある。 たとえば，和牛 の発育を著しく改善するとか，乳量を多くしてその余

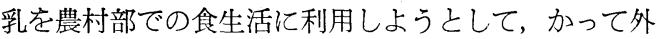
国種を和牛に交雑したととがあった．しかしその当 時, 増体量が大きくても，一代雑種は有利に販売でき なかった．また，いわゆる新乳牛がつくられたとき乳 量は多くなったむのの，その頃屯っと屯重要であった 水田における農作業に適さない足の太いものとなり,
結局てれも失敗したも゙.

それ以外に李，たとえば反すう動物は尿素のような 安い非たん白能崈素化合物を，たん白蛕源として利用 できろことが，消化生理学的に明らかにされた時，そ の正しい給与法に関して知識の不十分なわが国の卒産 経営では間違った利用をしたため, 初期の段階で中毒 の発生がみられた：そのため尿素の利用は，わが国で 普及をみると々が著しく渥れ，今であ低位に抑えられ ている．このように技術革新が経営変革をあたらすに 到るまでには，克服しなければならない問顥がいくつ あある。．今日，わが国で尿素の飼料的利用が年間わず か 6 千 $\mathrm{t}$ 之少ないのに，アメリカにおいては80万 $\mathrm{t}$ と きわめて多いのは，飼育頭数の湋いというよりあ，技 術革新を経営に尊入していくステップに大きい違いが あったためと考えられる．その意味において，糹産に おける新しい技術は，実証実験をくり返し，その間題 点が明らかにされた後，その採用について十分な教育 をうけた農業経営に普及されて，はじめて経営変革に まで僬むむの之考元られる7．幸い，そのような段階 を経て経嘗の現場に定着したいくつかの肉用牛生産技 術があるので，それを材料として技術革新と経営変革 を考えてみよう。

\section{3. 若齢肥育技術の開発と普及}

戦後の経済復興に伴って，昭和27年に麦の統制が撤 廃されると，和牛の肥育が再び活発になった． 戦前と 同じように，農村部で役利用と採肥を兼ねて飼育され ていた成牛をもと牛として，短期間の飼い直しで，肉 質の改善を行う程度の肥育が始められた．折しも, 戦 後の農村の活性化のためには和牛が必要であると認諳 されて，全国的に増頭が進んでいたので，屯と牛の入 手は比較的容易であった。 とてろが，まむなく，農業 用耕うん機の普及之，化学肥料の大量流通 が始まる と, 農用家畜之しての和牛の重要性が軽くなった。 そ こで昭和30年代になると, 多くの和牛が食肉用に出荷 され，安い価格で大量に出回わることになった3).

その時代に，牛肉はむっ之も大衆的な食肉之なると ともに，食肉需要は著しい増大を示しはじめた。 それ に応えて，豚肉や鶏肉の生産も盛んになったが，牛肉 は昭和 30 年代中頃まではもっ之も消費量の多い食肉で あった．しかし，やがて，農村部に和牛が少なくな り, 肥育もと牛として成牛を入手することが困難にな った，そこで新しい牛肉資源の涵養が必要之なった。 すなわち，従来のように成牛をもと牛とする雌牛中心 
の肥育にかわり, 新しい肥育方法の開発が望まれた. そとで和牛生産頭数の半数を占めながら, 肥育される こともなくそのまま屠殺される多くの雄子牛を去勢し て肥育し，食肉資源とすることが検討された。乙れ は，生産された雄子牛の経済的評価が，雌子牛と比較 して極端に低く，したがって，子牛生産農家の経営が 生まれた子牛の性によって大きい影響をうける時代に はとくに重要な意義をむつととであった ${ }^{9}$.

昭和29年には第 1 回の去勢肉牛研究会か潤催され, 将来のわが国の肥育について検討が行われた．その当 時, 肉牛として出荷される去勢牛の多くは $3 \sim 4$ 才, 雌の多くは8才以上であったが，将来はあっと若齢で 出荷しなければならないという点で, 認識が一致し た．そして，去勢牛肥育は，少なくとも20〜30力月齿 で仕上げ，肥育技術の向上によって目標体重を低下さ せず，肥育度を高めて，肉質を向上させ，あくまで精 肉用に出荷させることが合意された．また去勢の時期 あ，なるべく早期にするととも決った．それを実証す るため，上坂らは黒毛和種去勢牛を用いて，最初の若 齢肥育試験を行い，去勢牛の若齢肥育々は哺乳中の生 後 $2 \sim 3$ 力月で去勢し, 生後約 6 力月で離乳し, これ を約12力月間育成肥育し体重420～450kgの肉牛として 出荷する肥育と定義した ${ }^{9)}$ ．乙の若齢肥育は，もとも と，アメリカなど牛肉生産の先進国で一般的な肥育技 術であり，もっとも効率の良い発育がみられる時期を 利用して肥育するあのであった．しかし，農業の立地 条件の異なるわが国の農村にてれが定着するまでには さまざまな改変が必要であった．そのため，試験の研 究機関で数多くの実験が行われ，その成果が有効，か つ適切に生産の現場に活用されていった。
アメリカに怙ける若齢肥育は，その肥育期間が 3 〜 6 力月間之短かく，また，それに先立って，離乳子牛 を $3 、 4$ 力間，良質の粗飼料だけで飼育する有成期 間が置かれている ${ }^{10)}$. それは，離乳直後からの $4 、 5$ 力月間は筋肉の発育の盛んな時期にあたるので，たん 白質，ビタミン，ミネラルなどが比較的多く必要であ り，それをバランスよく供給してくれる飼料が良質の 粗飼料であるためである. しかし，わが国において は，広大な草地と良質の粗飼料が少なく，農家では必 ずしもこういう育成を行うことができなかった．そこ で，日本型の肥育技術として，良質粗飼料の給与量は アメリカより少ないむのの，たん白質の多い大豆粕，

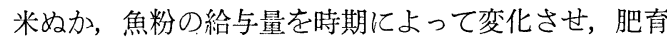
当初はそれらを多く利用し，肥育が進むにつれてそれ を減少させて，加ってとうあろこし，大麦を多く与 える飼料の配合設計がつくられた，肥育期間は当初 12 カ月間であり，その間に肥育用配合飼料の内容が 3 回 変えられることが一般的であった．乙うして，やが て, 生後 18 力月齢, 体重 $450 \mathrm{~kg}$ 加ら500 kgの肥育牛をつ くりあげるととが可能となった11).

試験研究機関におけるこの技術開発をうけて，若龄 肥育に取組む農業経営が各地に生まれた。彼らは，乙 の新しい肥育の技術手引きに従って，若龄肥育を成功 させるため，畑地に飼料作物を栽培して青刚利用した り，サイレージとして給与したりしながらなるべく多 くの自給粗飼料を利用した肥育を行った。 その過程 で，肥育形態別出荷頭数は表 1 のとおり，大きく変化 し若耠肥育はわが国の主な肥育方式の一つとなってい った.

表 1 肉牛肥育形態別山荷頭数（頭）

\begin{tabular}{|c|c|c|c|c|c|c|}
\hline & \multicolumn{2}{|c|}{ 雌 牛 } & \multirow{2}{*}{ 婎牛肥䢛 } & \multicolumn{2}{|c|}{ 去 勢 牛 } & \multirow{2}{*}{ 合 } \\
\hline & 普通肥育 & 理想肥育 & & 壮掬肥育 & 若齢肥育 & \\
\hline 昭 32 & \multicolumn{2}{|c|}{$\begin{array}{r}135,599 \\
(51.2)\end{array}$} & $\begin{array}{c}35,189 \\
(13.3)\end{array}$ & $\begin{array}{c}79,666 \\
(30.1)\end{array}$ & $\begin{array}{c}14,399 \\
(5.4)\end{array}$ & $\begin{array}{r}264,853 \\
(100)\end{array}$ \\
\hline 35 & \multicolumn{2}{|c|}{$\begin{array}{r}129,765 \\
(38.9)\end{array}$} & $\begin{array}{c}45,862 \\
(13.7)\end{array}$ & $\begin{array}{c}83,556 \\
(25.0)\end{array}$ & $\begin{array}{c}74,705 \\
(22.4)\end{array}$ & $\begin{array}{r}333,888 \\
(100)\end{array}$ \\
\hline 40 & $\begin{array}{r}184.391 \\
(33.9)\end{array}$ & $\begin{array}{r}24,686 \\
(4.5)\end{array}$ & $\begin{array}{c}47,519 \\
(8.7)\end{array}$ & $\begin{array}{r}120,244 \\
(22.1)\end{array}$ & $\begin{array}{c}167,482 \\
(30.8)\end{array}$ & $\begin{array}{r}544,322 \\
(100)\end{array}$ \\
\hline 45 & $\begin{array}{r}178,783 \\
(35.9)\end{array}$ & $\begin{array}{r}38,449 \\
(7.7)\end{array}$ & $\begin{array}{c}33,909 \\
(6.8)\end{array}$ & $\begin{array}{r}92,217 \\
(18.5)\end{array}$ & $\begin{array}{c}155,141 \\
(31.1)\end{array}$ & $\begin{array}{r}498,499 \\
(100)\end{array}$ \\
\hline 50 & $\begin{array}{c}96,308 \\
(26.3)\end{array}$ & $\begin{array}{r}28,577 \\
(7.8)\end{array}$ & $\begin{array}{r}21,157 \\
(5.8)\end{array}$ & $\begin{array}{l}82,189 \\
(22.5)\end{array}$ & $\begin{array}{r}137,294 \\
(37.6)\end{array}$ & $\begin{array}{r}365,525 \\
(100)\end{array}$ \\
\hline
\end{tabular}

\section{4. 経営方針にあわせた技術の微調整}

若柃肥育が全国的に一応の普及をみるまで，長期間
を要さなかったのは, この技術が比較的単純で, 習得 し易かったてとや発育の盛んな時期を利用して肥育す るので, 病気の発生も少なかったためである. 去勢若 
龄肥育牛の肉質は, 従来, 成牛からえられた牛肉に慣 れてきた流通業界で，はじめは評価が低かった．とく に肉色が淡い点での不満が多かったが，肉色を発現さ せる色素が，加㱓とともに增加する特性をもつだけ に，その改善は無理であった， しかし，肥育度の十分 な去勢若齢肥育牛が肉育市場へ多数出荷されたので, 市場側の評価は次第に高まった。

その後, 去勢牛若路肥育の技術は, 時代ごとに変わ る農家の経営方針にあわせて，次第に变化した．乙の 変化は試行錯誤を覚悟で新しい技術にとり組んだ先進 的な経営者が遭遇した問題点を, 試験研究機関がすば やく対応して解決し，その新しい技術を一般化し易い ように組み立て，全国に普及させたものであった．多 くの経営が望んだてとは, 収入の増大のために多頭飼 育にふみきることであった。

幸い, 離乳直後の去勢子牛は, 市場で比較的容易に 入手できた，そこで，飼育管理は単房式から，つなぎ 方式に変えられ， 1 頭当たりの畜舎面積は節約され， 飼育労働も著しく省力的になった，その後，さらに群 として肥育牛を管理し, 給䬣する方法として, 追込み 式が採用されることになった．その結果，一経営当た りの肥育牛頭数を著しく多くすることが可能となっ た．その際，一群当たりの面積之頭数について，ある いは，強弱関係からいじめられて発育の遅れる個体を なくすために，飼料を不断的に自由㩒取させる方法な ぞが検討されて，いろいろな立地条件の肥育経営に適 切な方法が採用されていっだ1).

若龄肥育牛の多頭飼育は，もともととの技術が購入 飼料を多く利用するむのであったので, 飼料基盤の大 きさに制約されることもなく実現し易かった. 一方， 良質粗飼料の増産は十分望めないので, 肥育牛 1 頭当 たりの粗飼料給与量か減少していった，その結果，多 くの経営で，屯ともと 1 年間の肥育期間中に青草換算 で゙, 000kg給与された粗飼料が，やがて，1,000 3,000 $\mathrm{kg}$ と減少し，不足分が稻わらとして給与されることに なった．その後，さらに良質粗飼料が不足し，粗飼料 としては稲わらのみを与えたり，さらにコンバインの 普及で稲わらの入手む困難となる条件下で，肥育を行 わなければならなくなった．青草とちがって，カロチ ンの少ない稲わら給与時には，持続性ビタミンAの注 射や, 飼料添加剂の積極的利用で, 肥育牛の健康状態 の維持を図る技術が生まれ，そ机に支えられて，肥育 経営は多頭化を続けた ${ }^{111}$.

ところで, わが国の牛肉消費の特徵の 1 つに, 霜降
り牛肉嗜好がある. そのためサシの十分入った牛肉 は，流通段階で喜こばれ高く取引されるととを肥育経 営が望んだとき, 若龄肥育の長期化と仕上げ体重の上 昇が始まった. 肥育度を高めるためには，栄養学的に この実現を可能にするような給与体系をつくらなけれ ばならない。

一般に肥育牛に給与される飼料は栄養学的には二つ に大別できる.一つは，牛の体重に増減をきたさず， 一定に保つための養分を供給する維持飼料，むう一つ は，牛の体組織とくに体脂肪を増加させ，体重を増加 させるための養分を供給する生産飼料である，肥育の 効率をよくさせるためには，給与飼料の中で生産に使 われる後者の量ができるだけ多いほうが望ましい，む し，エネルギー含量の低い粗飼料が多給されているな らば，牛は無限に飼料を食べるわけではないので，大 部分が維持に利用され，增体量は大きくならない，そ のため，肥育時には穀頪のようなエネルギーの多い飼 料をいかに多く食べさせるかが大切となる。

しかし，あともと草類を主食として生きてきた反す う動物が，穀類の多い飼料を給与されると，生理的な 代謝障害を起こすととがある．とくに極端な濃厚飼料 多給，粗飼料少給の条件で長期間の肥育を行う之，肥 育牛にルーメンパラケラトーシス，ルーメンアシドー シス, 肝膿腸, 下㾥症, 鼓脹症, 尿石症, 盲目症, 肢蹄異常などの発生がみられる. それらを防止するた め, 試験研究機関はさまざまな研究を行った。

濃厚飼料の配合内容を変えて, 高エネルギー飼料を つくり，増体量を大きくし，飼料用の穀物の物理的形 態を変えて，消化管内での分解速度を制御したり，給 慨方式を変えて肥育中の疾病の発生を少なくした．ま た穀物を加工処理することも一般化し，肥育中の増体 率がさらに改善された：それとともに，ビタミン類， ミネラル，抗生物質などが飼料添加剤の中に入れられ たり，さらには発育促進の目的で，ホルモン剤の投与 あ行われ，肥育効率はさらに上昇することになった。 屯ち万ん，こうした肥育技術の開発時に，微量な有害 成分の残存が人間之肥育牛の健康に悪影響があるとと が明らかとなって，その使用が禁止されたあのもあ $ろ^{5}$.

こうした試行錯誤のくり返しの中で，技術革新によ って, 肥育牛の仕上げ体重は, 著しく増加した（表 2 ）.

今日のわが国の肥育経営は，世界的にみても，例が 少ないほど大きい仕上げ体重の肥育牛を出荷している が，それは経営が望んだ方向に沿った技術開発が行わ 
表 2 去勢肥育牛の販売時月齢と体重

\begin{tabular}{|c|c|c|}
\hline & 月 & 出荷体重 \\
\hline 昭 35 & 35.5 力月 & $456.2 \mathrm{~kg}$ \\
\hline 40 & 20.4 & 449.5 \\
\hline 45 & 23.9 & 515.7 \\
\hline 50 & 26.9 & 587.9 \\
\hline 55 & 27.9 & 613.1 \\
\hline 58 & 28.8 & 632.9 \\
\hline
\end{tabular}

注) 肉尃用種, 童産物生産費調査. 昭40以降は, 去勢牛若舲肥育.

れた結果である. しかし，私経済における利益の追求 が，十分な経済的分折のないまま行われた面ああり， 今日わが国の牛肉生産コストはきわめて高くなった. 技術開発する側は比較的規模の小さい肥育経営が追求 する方向が正しいかどうかを十分吟味することなし に，当面の技術的問題点の解決に没頭してきた感があ るととは否定しがたいととである.

\section{5. 乳用おす哺育育成技術の開発}

乳用おす子牛を肥育して, 精肉用に利用する例は, 昭和 40 年以前のわが国では比較的少なかった．おす子 牛は，生後まむなく屠殺され，その時代に次第に生産 量が多くなった廉価なプレス八ムの原料肉として利用 されることが一般的で, 本格的に肥育されることはご くまれであった，ところが，昭和 30 年代に急增した牛 肉需要に和牛肉の増産では次第に対応しきれなくな り，乳用おす子牛を肥育することの重要性が認識され るととになった，しかし，酪農経営においては，更新 用のめす子牛の育成時に全乳もしくは脱脂乳を用いて 哺育することはあってあ，おす子牛にそれを給与する ことは経済的に有利と考えられていなかった。 そて で, 新生子牛を人工的に育成する技術の開発が重要に なった. その際に，とくに役立った知見は，初乳の重 要性の認識之新生子牛の消化生理上の特色の確認であ った．その結果，すぐれた子牛用の代用乳（ミルクリ プレーサー) と人工乳 (カーフスターター) の開発が 行われた ${ }^{12}$.

初乳の中には，常乳の $3 \sim 4$ 倍あのたん白質が含ま れ，しかもこの50～60\%が免疫グロブリンである. そ のため, 初乳を摂取することによって，子牛は母牛か ら免疫物質を与えられ，種々の疾病に対する抵抗力を 身につけることができる. 初乳のこのような特性は分 婏 3 日後くらいで急激に失われるが, 新生子牛が初乳 を十分飲んでいるか否かによって，その後の哺育成績 に決定的な影響が現われる．初乳を十分领まなかった
子牛は, 死亡率が $50 \%$ 以上というととあある. したが って乳用おす子牛の肥育技術体系の確立はまず, 初乳 の役割の確認から始まったのは当然のととであった. 今日では新生子牛を導入するとき, 子牛の血液検查を 行って, 初乳を十分飲んでいるか否かを判断している 経営あ生まれているほど，乙れは重要なととである。 酪農経営で生産された新生子牛に初乳を必ず飲ませて から，6〜10日齢で哺育育成経営に導入することが, 一つの技術と認識されたことは大きな技術革新であ り，それに伴ってその後の哺育育成を担当する経営に おける子牛の管理面での労働力は著しく軽減されるこ とになった ${ }^{13)}$.

つぎに母乳に変って新生子牛に有効に利用できる栄 養源を, 経済的に安く供給する目的で, 代用乳之人工 乳との成分の栄養学的研究が行われた. 代用乳之は, 哺乳初期に子牛に給与する母乳の代用品であり, ふつ j 5,6 週秢まで給与される. 乙れは脱脂粉乳之乾燥 ホエーが主な成分であるが，それに良質の植物性脂 肪, 粉砕された款類, ビタミン類, 微量栄養素などを 配合し, 牛乳固形分に近い屯のをつくり, これらを温 湯溶功て給与するのである. しかし，母牛から直 接母乳を领む場合とちがい，母子分離によって新生子 牛を人工的に飼育するには, 多くの困難があり, それ を克服するために活発な技術開発が行われた ${ }^{5}$.

母牛の乳首からの自然哺乳の場合, 母乳は反すう胃 に入らず，直接第 3 胃を経て第 4 胃へ入る：乙れは食 道溝反射という特別の機能があるためである. 乳汁が 反すう胃に入る之, そこに棲む微生物の働きで, 発酵 が起こり, 乳汁の主要な栄養源のカゼインと乳糖が分 解され, 利用效率が低下する. しかし, 食道溝反射に よって，第 4 胃に送り込まれるとてれらの栄養源は効 率よい消化をうけることになる，とてろが，人工的に 代用乳を給与するときには，食道溝反射をうまく誘起 できるかどうか大きい関心事となった．研究の結果, 人工哺育の場合でも, 日常的な習慣づけで, 条件反射 的に食道溝反射が起こることが明らかにされた. そし て，代用乳を給与するとき，バケツから直接飲ませる よりむ, バケツに人工的な乳首をつけ，それを通して 少しずつ哺乳させるほうが, 第 4 胃内でカードの形成 が十分となり, その後の消化管内の移動速度む遅くな り，代用乳の消化性が高まるととが明らかになった。

このように消化生理上の特徵が理解され, 代用乳給 与が合理化されることによって, 乳用おす子牛の育成 において経済的に多大な損失を生じさせた新生児下㾥 
症の防止が次第に可能になった，さらには，代用乳給 与期間中に感染症にかかることを防ぐための研究屯行 われ，最近では，出生直後の子牛を母牛から隔離し て，牛舎外につくったカーフハッチと呼ばれる別飼い 用の犬小舎のような施設で哺育するととが多くなっ た。乙れを採用した後に，従来20\%以上の損耗率であ ったあのが，5\%以下になった経営もある14).

代用乳住続いて子牛に給与される人工乳は，いわば 離乳飼料であある。乙れは，価格の高い乳成分を含ま ず，良質の植物油粕類，穀類，ぬか類が主原料で，そ れに微量栄盖素が添加された一種の配合飼料であり， マッシュやペレットとして，固型物のまま子牛に採食 させる. てれを㨟取している間に子牛の消化器官は機 能的に十分な粗飼料と濃厚飼料を消化できるところま で発達し, 肥育もと牛として利用できることになる。

今日ではこれらの飼料を利用して, 生後13週龄で離乳 させる早期離乳技術が一般化した．その場合，生後 1 週齢でろから人工乳乾草を子牛の前に置き，代用乳 を給与されている子牛を，なるべく早い時期からそれ らを食べることに慣れさせ，早く反すう胃の機能を発 達させるわけである13!

とのようにして乳用拈す子牛を人工的に哺育・育成 した後は，肥育期に入るが，乙の時期の飼養管理は， 肉用種の場合とほとんど同じである. 乳用おす子牛 は，従来経済的に肥育むと牛まで育てることが困難な あのであったが，飼盖管理技術の革新によって，それ が可能になった．その結果，乳用打す肥育牛から生産 される牛肉は 表 3 に示すとおり, 急激に增加し た.

表 3 枝肉生産昷とその内沢

\begin{tabular}{|c|c|c|c|c|}
\hline & \multirow{3}{*}{ 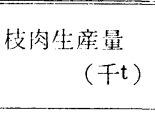 } & \multicolumn{3}{|c|}{ 枝肉種類別棈成比 100} \\
\hline & & \multirow{2}{*}{ 和 4} & \multicolumn{2}{|c|}{ 乳 4} \\
\hline & & & 肥青扰す & 乳用めす \\
\hline$\left.D_{i}\right\} 42$ & 154 & 65.0 & 4.2 & 30.8 \\
\hline 43 & 171 & 57.9 & 14.6 & 27.5 \\
\hline 44 & 228 & 56.6 & 18.2 & 25.1 \\
\hline 45 & 270 & 56.0 & 14.0 & 30.0 \\
\hline 46 & 290 & 54.8 & 10.7 & 34.4 \\
\hline 47 & 314 & 50.5 & 17.1 & 32.4 \\
\hline 48 & 244 & 41.5 & 23.9 & 34.6 \\
\hline 49 & 317 & 34.4 & 32.0 & 33.6 \\
\hline 50 & 348 & 37.4 & 30.0 & 31.9 \\
\hline 59 & 536 & 37.0 & 32.4 & 30.6 \\
\hline
\end{tabular}

昭和 42 年にはわずか $4,2 \%$ であった乳用おす肥育牛 の牛肉は，49年以降 $30 \%$ を超えているが，乙れには技 術鞾新が果した役割はきわめて大きい，とくに，乳用
おす子牛は，和牛と比較して価格が安く，また，肥育 期間中の増体量が大きいとともあって，資金回転が早 く，乳用おす肥育経営は飼盖規模が大きくなり，わが 国における大規模な肥育経営の大部分が，乳用おす肥 育で占められるようになった，その様相を，農家1戸 当たりの乳用種肥育牛飼育頭数でみると 表 4 のと おりである.

表 4 肥育経営における乳用種肥育牛飼育規模

\begin{tabular}{r|c||r|r}
\hline \hline 年. 次 & 顽 / $\boldsymbol{~}$ & 年 次 & 䫓 / 户 \\
\hline 昭46 & 10.6 & 昭53 & 27.9 \\
47 & 16.9 & 54 & 30.2 \\
48 & 24.8 & 55 & 32.1 \\
49 & 27.6 & 56 & 35.2 \\
50 & 25.6 & 57 & 35.8 \\
51 & 25.4 & 58 & 35.5 \\
52 & 26.7 & 59 & 35.5 \\
\hline
\end{tabular}

注）肉用牛統計資料.

したがって，飼盖技術の革新は，大きい経営変革を もたらしているととがわかる.

\section{6. 人工授精技術の開発亡普及}

牛の繁殖に人工授精を採用しはじめた動機は，伝染 病の予防にあった. 昭和 3 年頃に畜産試験場内で結核 が览延したとき，その防止に人工授精が行われた。 そ の後, 昭和 7 年頃から, 繁殖牛の生殖器病の防除の目 的で，広く人工授精が採用された。その結果，とくに 繁殖障害をむたらしていたトリコモナス症はわが国か らはほとんど姿を消した．当時この新しい技術革新が あたらした経済的効果は測り知れないほど大きいもの といわれた. 戦後, 家畜改良增殖計画がたてられ, 緊 急增殖の手段之して人工授精が採用され, 全国的に著 しく普及しだ.5.

人工授精が，適切に実施されると，家畜改良の促 進, 雄の飼育頭数の減少による飼育経費の節減, 受胎 率の向上，伝染病の予防などさまざまな利点がある. なかであ顕著なととは生産能力の向上に対する效果 で，たとえば，乳用牛における1頭当たりの年間搾乳 量は，人工授精の普及率が $50 \%$ 程度であった昭和 24 年 には，2,600 kgであったのが，90\%を超えた 29 年には 4, $200 \mathrm{~kg}$ となった. 屯ちろん, この向上には, 飼養管 理の進歩も影響しているが，泌乳能力の著しい上昇に あっとあ大きく役立った技術は人工授精であったとい われる. 肉用牛の改良における人工授精の効果は, 乳 用種の場合ほど顕著ではないが，黒毛和種産肉能力直 
接検定の成績が，昭和41年から50年まわの間に, 365 日 齢補正体重で1，13倍，また 1 日平均増体量で1，28倍と なった事実の一部は，人工授精技術の発展によって， 少数精鋭の種雄牛を効率よく使って, 雄側の優良形質 を広く用いたと之によるものであろう。

今日，牛の人工授精においては採取された精液は， 希釈処理に先立って, 短期間に精子の生存率之運動性 が検査され，同時に正確に精子濃度が人工授精に供用 しうるかどうか，また希釈倍率をどの程度にすべきか

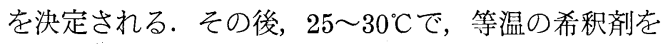
徐々に加え, やがて $4{ }^{\circ} \mathrm{C}$ の恒温室内で $1 \sim 3$ 時間かけ て 4 ㄷ冷却する. 乙の希釈液は, 畉黄緩衡液で，そ の内容は多くの実験が行われた結果, 良好のものがつ くられている.ささらに，精子を，液体窒素内で超低温 条件下で保存する技術も開発されており，保存期間が 20 年にわたっても，新鮮な精子を用いたときと同程度 の受胎率があることあ知られている(1).

牛の繁殖において, 自然交配では, 1 回の射精で, せいぜい1頭の雌を受胎させるにすぎない，しかし， 人工授精では，精液をこのように希釈できるので，は るかに多くの雌に受胎されることが可能である．牛の 1 回の射精量を $5 m$ lとすると, 1 射精の精子数は 65 億 である. 理論的に 1 授精に当たり必要とされる精子数 は 0,2 億でよいから， 1 射精で授精可能な頭数は 325 頭である.あち万ん，現実的にはこれだけ効率のよい 生産は行われていないが，種雄牛 1 頭当たり；従来の 自然交配では，年間100〜150頭の雌に種付するのが普 通であったが，今では人工授精によって 10,000 頭以上 に授精できる例む珍しくない16)。昭和23年からの 20 年 間に急激に認められた人工授精の普及率の上昇とそれ に伴う種雄牛頭数の減少は表 5 のとおりである.

表 5 肉用牛に扔ける人工授精の恶及

\begin{tabular}{r|c|c}
\hline & 普及率 & 種雄牛頭数 \\
\hline 昭 23 & 約 $10.0 \%$ & 6,789 頭 \\
26 & 35.2 & $7,693($ 昭 25) \\
30 & 74.1 & 4,820 \\
35 & 86.7 & 3,043 \\
40 & 90.7 & 2,200 \\
43 & 94.1 & 1,894 \\
\hline
\end{tabular}

人工授精の普及は, 品種改良に大きな貢献を期待で きる少数の種雄牛の精液の広範な利用を可能にし, 同 時に, 種雄牛頭数の減少により, 気の荒い雄牛による 人身事故の発生を減少させた．とくに最近では，種雄 牛の管理が集中的に行われることが多くなり, 種雄牛
と飼炁環境は改善され，健康的に長期間供用できると ともに，管理面での安全性あ高くなった．それに加え て, 種雄牛頭数の減少は, 飼料養分の節減をむたらし ている. 労力の節約についても，種付けのために一日 がかりで雌牛を引いて山道を歩くことはなくなり, 種 雄牛を小さな牧野組合で飼育する必要性がなくなった ことなど，人工授精があたらした経営変革はきわわて 大きいあのがある.

しかし，人工授精という画期的な技術革新屯，経営 対応が不十分なときには，その効果を十分発揮するこ とができない，たとえば，受胎率の向上が人工授精普 及の一つの大きなきっかけであったが, 生殖器病の予 防が可能となってからは，受胎率が十分高い水準を保 ちつづけているとは言えない，一般に人工授精におい て, 適期授精を実現するためには, 経営者は雌牛の発 情の発見につとめなければならない，しかし，畜舎が 喑すぎたり，人手不足で鑑察が不十分で，発情の発見 ができなかったり，不適切な飼養管理を行って，栄養 の過不足から受胎率が低功たりして，折角進んだ技 術があるのに，それを十分活用できない経営がなお多 くある. その結果，放牧地带に今もな报られた頭数 でみられるまき牛による自然交配のほうがかえって高 い繁殖率を示しているのは，皮肉なととである，技術 革新が経営変革をむたらすには，経営者側の努力が必 要なととを示す一つの例である゙”.

\section{7. 技術革新と経営対応}

$「$ 必要は発明の母なり」と言う言葉のとおり，畜産 業の現場汇新しい技術が必要之されるとき，何かのき っかけで生まれた新しい技術の芽が大きく育ち，技術

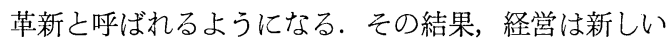
技術を生かし，経済的に大きな成果をえて，経営変革 が起こる．技術革新のきっかけは，すぐれた研究者の 独創的な発明，発見によるむのもあるが，畜産におけ る今までの経験から考えるとむしろ生産現場の先進的 な経営が試行的に新しい技術に挑戦してそのきっかけ をつくるほうが多い，すなわち，生産に直接従事して いる人々が彼らをとりまく瞢境の中にあって私経済的 に有利な展開方向を求める意欲の強さによって新しい 技術がくり出されることが多い，しかし，それが特定 の経営では成功しても，一般的には普遍的な技術とは なりえないものが多く，それを模做した多くの経営で 失敗が起こり経済的に大きい損害をこうむり，そこで 初めて新しい技術に大きい関心が集まる，そてで，研 
究者がその新技術の問題点の検討を始め, やがてそれ を比較的安定した失敗の少ない技術にまで改善する。

こうなって新しい技術がはじめて全国的に普及してい くことも多い.

ところで，前述した初生雛雌雄鑑別をみれば，初生 雞の中から雌のみを選んで飼育ができればよいという 希望は一般の経営に多かったととが背景となってい る. また，去勢牛若齢肥育や，乳用打す子牛の哺育育 成は，農業をとりまく環境の変化によって，新しい牛 肉資源の涵養が強く望まれた条件下で, 農業経営が新 しい収入増加の途をさがしはじめたととが技術革新の きっかけであった，さらに人工授精技術の開発は，当 時, 自然交配時にさけがたかった生殖器疾病による繁 殖率の低さを克服したい希望が現場に強かったためで ある. しかしそのような事情をうけて研究開発が行わ れはじめた後の展開はさまざまであった。

初生篗雌雄鑑別技術はつぎのような経緯をたどっ た.まず，農林省畜産試験場で家畜家禽の繁殖につい ての研究を委嘱された東京帝国大学の増井清助教授ら が倠雄成蹈の排泪腔の解剖学的研究を行っていると き，去勢試験用の対照雄成舀の肛門を強く開いた之 き，下壁中央に麻の実状の突起を発見した. しかし， 雌成鷄にはこれがなかった，そこで彼らはそれが雄鵎 の交尾器官であると推論して研究を進め, やがて初生 绉倠の雌雄鑑別法を考案し, 学会で発表した. その成果 を当時の孵畉業の中心地であった愛知県の養鷄業者が 注目し，実用化に向けて努力した，そして学会発表 の 2 年後の眧和 2 年, 「雌量九割責任付初生炡」之い う広告を出す業者屯現われた. こうして, 雌雄鑑別法 の実用化が進んだが，学術的研究にはなお不備な点が 多いため, 研究者はさらに詳細な研究を行うことにし たが，そのとき業界は協会を通して研究のための資金 と材料を提供し，乙の新しい技術を一層精度の高い屯 のとした. やがて初生雛鑑別師という新しい職業が生 まれるに到って新技術は現場に生きることになった。 この段階で, 採畉養鵎における経営变革が始まった。

去勢牛若柃肥育においては, 肥育の盛んな府県の試 験場や大学に, その地域において問題となった技術的 課題が，たえず持ちこまれ，官民一体となった技術開 発が行われた. 京都大学の上坂章次教授を中心とした 研究グループは，限られた予算の中から肥育もと牛を 購入し, 毎年新しい肥育試験を行い, その成果を刊行 し, 広く全国の研究機関や農業団体に送り，また，全 国各地で肉用牛農家を集めて，わかり易く肥有技術を
解説した. さらにそのとき話題となった現場での問題 点を研究室に持ち㷌り, 解決法を研究してすばやい回 答を生産現場に送っていった．若齢肥育においては, 雌雄鑑別師のように特別の職業は生まれなかったが, 地域でとに情熱のある技術者が現われ，熱心に新技術 の開発と普及にあたり, 肥育産業の振興をむだらし た.

人工授精技術については，農林省畜産試験場の西川 義正博士を中心とする研究によって, その利点が十分 明らかにされていたが, 和牛については昭和 22 年の家 畜改良增殖五力年計画においてその積極的応用が国家 的に採りあげられた. その後, 昭和 25 年の家畜改良增 殖法の制定で人工授精は急速に普及することになっ た. 人工授精を行うことのできる有資格者は獣医師と 都道府県その他の機関で行う所定の講習会を受け特定 の試験に合格したあのに限られているが，てれによっ てすぐれた人工授精師が数多く生まれた. そして彼ら に支えられて，乙の技術は急速に畜産の現場に普及 し，さまざまな経済的効果を生むととになった。

このように畜産における技術革新が経営変革をもた らした経緯をみると, その多くは小規模な研究から出 発しながらも, 畜産業が当面する大きい問題点を解決 する方向に動き出し，やがて多くの実証試験によって 新しい技術となってから組織的な普及を通して, 経営 に波及的効果をむたらしていることがわかる.

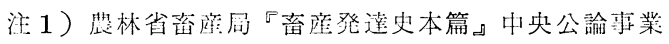
出版, 1966, 1115 1120 .

2）间上, $1178 \sim 1194$.

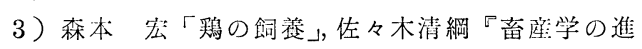
庭』答賢堂, 1961，517～528.

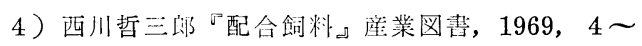
5 .

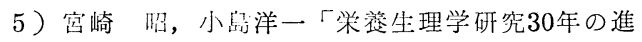
步, 肉用牛について」栄鉴生理研究会報』29 (1), 1985, 89 107,

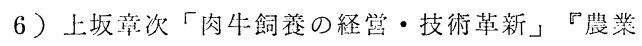
および㖥芸』 45 ( 1 )，1970，263〜268.

7 ）容崎昭「アメリカ畜産における宸菜改良普及 制度」『畜産の研呪』38（10），1984，1209～1214。 宮崎炤, 小㽞洋一「英国音産における農業改良 普及制度」『畜産の㼋究』39 $(3,4), 1985,409$ $\sim 413, \quad 515 \sim 518$.

8 ）小野茂樹「肉用牛経営の变遷」，全固肉用牛協

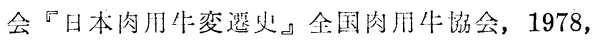
131 199. 
9 ）上坂章次, 犬塚澄雄, 斉田二郎「去勢牛の若齢 肥育に関する研究 第 1 報」『京都大学莚学部畜 産学研究室業績』115, 1967.

10）吉田忠, 宮崎昭『アメリカの牛肉生産』農 林統計協会, 1982 .

11）川島良治「肥育牛の飼養」全国和牛登録協会， 『和牛の進歩』全国和牛登録協会, $1977,45 \sim 67$.

12）福島豊一「乳用種 の肉利用」全国肉用牛協会 曰日本肉用牛変選史』全国肉用牛協会，1978，81 $\sim 113$.

13）宫崎昭, 小島洋一「イギリスの牛肉生産 （2）」『畜産の研究』39（10), 1985, 1279
1283.

14）宮崎 昭「肉用牛增頭計画一ビーフプラン2001」 『畜産の研究』 40 (1), 1986, 122 128.

15）西川義正「家畜人工授精」佐々木清綱『畜産学 の進展』養賢堂, 1961，376〜390.

16）入谷 明『バイオテクノロジー 畜産領域での 応用」臨床栄養』 68 (1), 1986, 42 46.

17）宮崎昭「わが国の経済的牛肉生産の技術的可 能性に関する提言」『畜産の研究』 $39(1,2)$, 1985, 144 148, 275 279.

（筆者・京都大学農学部） 